\title{
ASSESSMENT OF OPTIMUM YIELD OF GROUNDWATER WITHDRAWAL IN THE YOGYAKARTA CITY, INDONESIA
}

\author{
Doni Prakasa Eka Putra*1, Muhammad Iqbal ${ }^{1}$, Heru Hendrayana $^{1}$, and Thomas Triadi \\ Putranto $^{2}$ \\ ${ }^{1}$ Geological Engineering Department, Faculty of Engineering, Gadjah Mada University, Yogyakarta, Indonesia \\ ${ }^{2}$ Institute of Hydrogeology, RWTH Aachen, Germany
}

\begin{abstract}
The high demand of clean water supply and groundwater usages in Yogyakarta City, Indonesia has caused the lowering of groundwater table of about 3 $m$ in average since 1984. This condition is caused by the increase number of groundwater pumping in this city relate to the rising of the urban population, economics condition, education and cultural activities, change of land use and increase number of hotels on this famous tourism city in Indonesia. Therefore, it became necessary to assess the optimum yield from the groundwater system beneath this city which can still preserve the recent level of shallow groundwater. This is important because most of the people in this city depends their daily water supply from shallow dug well. In order to assess the safe yield, a groundwater modeling is conducted. The data used on this modeling was taken from previous research and also primary data collected during this research such as; aquifer geometry, aquifer characteristics, shallow groundwater level, water usage/pumping wells discharge, river discharge and surface water level, and climate data. Prediction of the impact of groundwater pumping was made by increasing the water usage/pumping wells discharge on several scenarios. The result of this modeling shows that the optimum yield of the aquifer beneath Yogyakarta City area is about 125,000 $\mathrm{m}^{3} /$ day.
\end{abstract}

Keywords: Optimum yield, groundwater usage,

${ }^{*}$ Corresponding author: D. P. E. Putra, Department of Geological Engineering, Faculty of Engineering, Gadjah Mada University, Jl. Grafika 2 Yogyakarta, 55281, Indonesia. E-mail: putra_dpe@yahoo.com groundwater table, pumping, urban population, shallow dug well.

\section{Introduction}

Yogyakarta is the famous education, cultural and tourism City in Indonesia. It's located in the lower slope of Merapi Volcano of Java Island (see Figure 1), and has about one million inhabitants. In this city, the daily water supply for each usage is taken from the groundwater resources despite there are four parennial rivers flowing near and through the city. The recent amount of groundwater withdrawal in this city is known to be about $45.000 \mathrm{~m}^{3} /$ day (Iqbal, 2013) and its already cost the decrease of groundwater level of about $3 \mathrm{~m}$ in average compare to the groundwater level in year 1984 . Therefore, in order to sustain and conserve the groundwater resources in this city, it is important to assess how much actually the optimum yield of groundwater withdrawal which can be applied in Yogyakarta City without causing unacceptable decrease of recent groundwater table. To answer the question, a groundwater model can be used to simulate several scenarios of groundwater withdrawal and the optimum yield of groundwater abstraction can be defined for Yogyakarta City. 


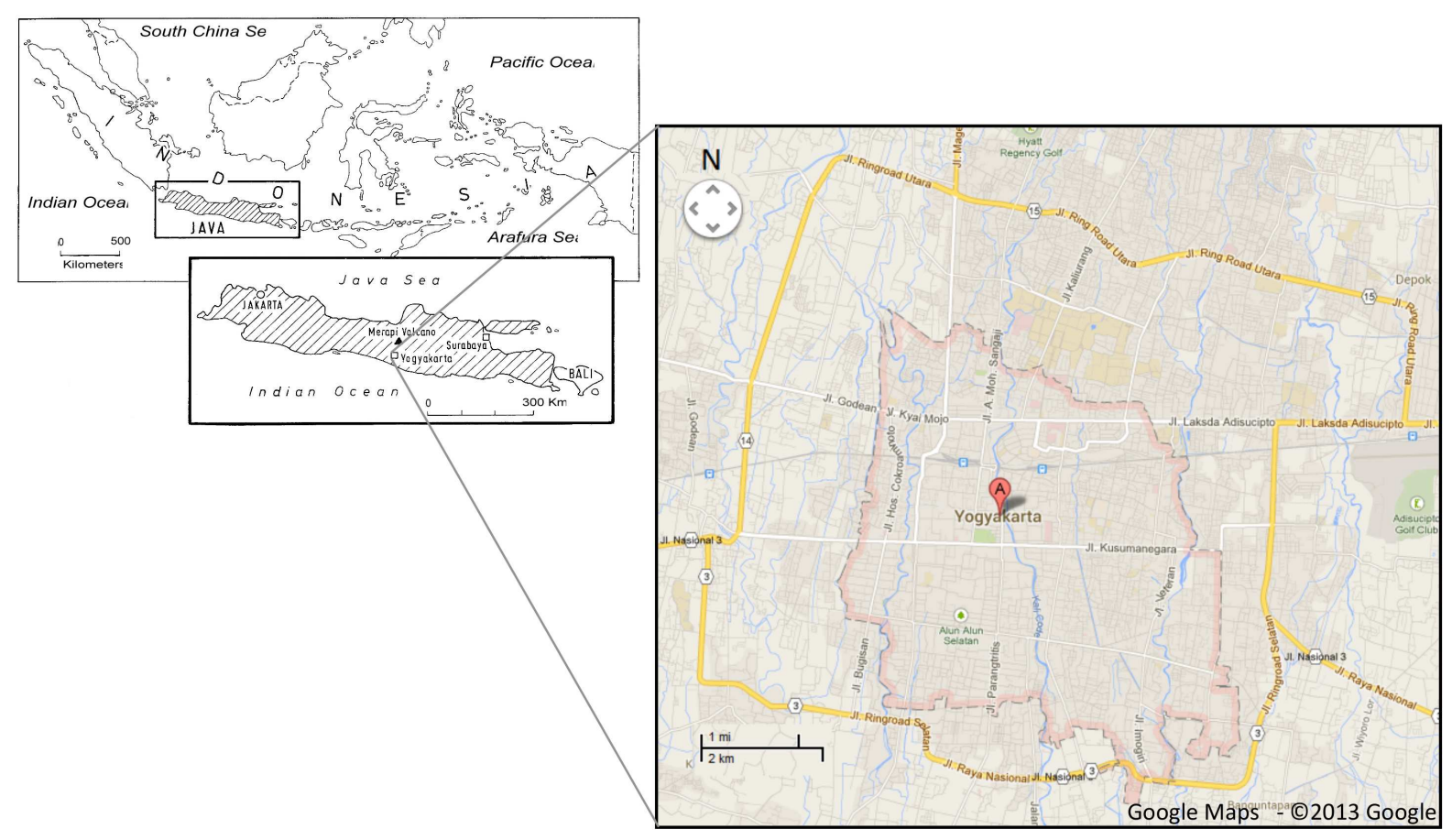

Figure 1: The location of the study area.

\section{Literature study}

In term of groundwater basin, Yogyakarta City is located in the central part of the Yogyakarta-Sleman Groundwater Basin, which is a part of groundwater-province from Merapi-Stratovulcan (Hendrayana, 1993). The Yogyakarta-Sleman Groundwater basin is mainly composed by the quarternary fluvialvolcanoclastic sediments. The term fluvial relate to the streams/rivers deposition process, and the term volcanoclastic is used because these quarternary sediments are largely attributable to Merapi Volcano deposits. Rahardjo et al. (1977) named these quarternary fluvial-volcanoclastic sediments as Young Merapi Alluviums. MacDonald and Partners (1984) differentiated the Young Merapi Alluviums into two types of Formation; Yogyakarta and Sleman Formation. The Yogyakarta Formation forms the surface outcrop throughout most of the lowland area of the Yogyakarta Basin from the Merapi Middle Slopes to the coast. It constitutes the upper part of the former Younger Merapi Volcanics. On the other hand, The Sleman Formation is designated as a lower part of the former younger merapi alluviums. The for- mation extends from the Merapi Upper Slopes to south of Bantul. This quarternary sediment succession built an aquifer system, which is named as Merapi Aquifer System (MacDonald and Partners, 1984; Hendrayana, 1993).

The Merapi Aquifer System is differentiated into two main aquifers; Yogyakarta Formation predominantly as the upper aquifer and Sleman Formation predominantly as the lower aquifer (MacDonald and Partners, 1984). The base of the aquifer system is developed by compacted breccia and lava layers of Old Merapi Volcanicdeposits in the north. In the central and south of the Yogyakarta City, limestone, marl and tuff of Sentolo Formation lye under the Merapi Aquifer System. In much of the region, the base of the system is in low-permeability rock (MacDonald \& Partners, 1984) and commonly designated as aquiclude (Hendrayana, 1993) hence some borehole data show that in some areas, the base of the system acts rather as aquitard than aquiclude. The system consists of sediment units varying in age from lower Holocene to recent time and is composed by interbedded middle to coarse sands, gravels, silts, clays and lenses of breccia. As the source of sediments originates mainly from the eruption materials 
of Merapi Volcano, andesitic-siliciclastic sediments are dominant. In the upper aquifer, sand and gravels are to be more prevalent in the top 10 to $25 \mathrm{~m}$ (MacDonald and Partners, 1984). But regionally, the lower aquifer consists of coarser deposits than the upper aquifer (Hendrayana, 1993). The thickness of the Merapi Aquifer System is distributed differently depend on the geological condition. Regionally, it increases from north-boundary of the aquifers to the central part of Yogyakarta City, and then decreases when exceeding the Yogyakarta graben.

Putra (2007) mention that the results of the lithostratigraphy correlation from borehole data within the study area show there are actually five quarternary layers or successions, which built the multilayer aquifers of the Merapi Aquifer System beneath Yogyakarta City (Figure 2). Each layer consists of a heterogeneous composite of gravel, sand, clayey sand, and clay facies, and they are separated by laterally uncontinuous sandy silt to clay layers. The laterally uncontinuous semi-permeable to impermeable layers make incomplete separation between the aquifers and cause hydraulic windows. As a consequence, the aquifers of this multilayer system are connected directly to each other in some places. The existence of hydraulic windows in the aquifer system in the study area can have an important role. The hydraulic windows allow mixing process of groundwater from different aquifers. Its mean that groundwater withdrawal in the lower aquifer system can also affected the upper aquifer and vice versa.

According to the constructed hydrogeological section (Figure 2), the thickness distribution of the Merapi Aquifer System is controlled by the basement morphology. The thickness of the system increases slowly from northernpart of the study area $(+50 \mathrm{~m})$ to the north footwall $(\mathrm{FW})$ of Yogyakarta graben $(+80 \mathrm{~m})$ and then increases abruptly in the central-part of Yogyakarta City $(+150 \mathrm{~m})$, attributable to the hangingwall (HW) of Yogyakarta graben. When exceeded Yogyakarta graben, the thickness of the system decreases, abruptly in the south footwall of Yogyakarta graben $(+50$ $\mathrm{m})$ and then decreases continuously to the southern-part of the study area $(+30 \mathrm{~m})$. From the total thicknesses of the system, thicknessess of the upper aquifer in the study area varies from about $25 \mathrm{~m}$ in the northern-part of the study area to about $45 \mathrm{~m}$ in the centralpart of Yogyakarta City and then decreases to about $10 \mathrm{~m}$ in the southern-part. The upper aquifer is composed mainly of middle to coarse sands and gravels. According to MacDonald and Partners (1971), the average hydraulic conductivity of this upper aquifer under Yogyakarta City is reported as about $7.8 \mathrm{~m} / \mathrm{d}$ (Putra, 2007). The storativity of the aquifer under the Yogyakarta city ranges from 0.03 to 0.20 , and based on the measurement from Alpin Consult (1989), the average specific yield of the upper aquifer is reported to be about $20 \%$. The thicknessess of the lower aquifer in the study area ranges between $20 \mathrm{~m}$ (southern-part of the study area) and $105 \mathrm{~m}$ (central-part of the study area), and is composed mainly by coarse sand with gravels and blocks, lenses of breccia and also lava layers.

\section{Theoritical background}

Considering a unit volume of porous media in the study area, the law of conservation of mass for a steady state condition is applied. It requires that the rate of fluid mass flowing into the aquifer system must be equal to the rate of fluid mass flowing out of the aquifer system. The equation of continuity that translates this law into mathematical form can be written as (Freeze and Cherry 1979):

$$
\frac{\partial}{\partial x}\left(K_{x} \frac{\partial h}{\partial x}\right)+\frac{\partial}{\partial y}\left(K_{y} \frac{\partial h}{\partial y}\right)+\frac{\partial}{\partial z}\left(K_{z} \frac{\partial h}{\partial z}\right)=0
$$

Where:

$x, y$, and $x$ the Cartesian coordinates,

$K_{x}, K_{y}, K_{z}$ the hydraulic conductivity components and

$h$ the hydraulic head.

Based on the mathematical formulations above, the groundwater head is calculated by an iterative process in the numerical model. A numerical model is one of the methods used to solve 


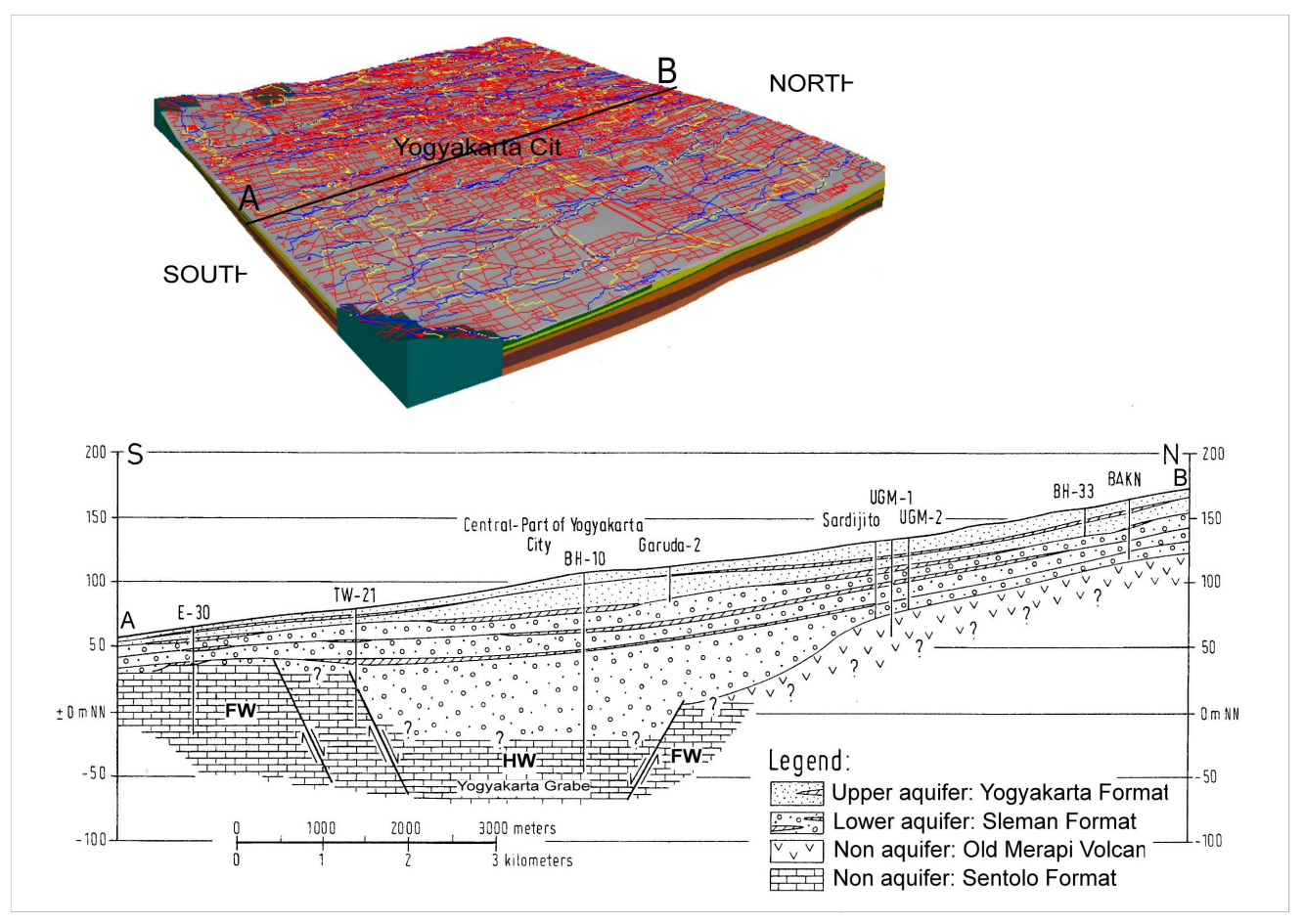

Figure 2: Concept of aquifer system underlying Yogyakarta City area (Putra, 2007).

groundwater problems in a hydrogeology science (Spitz and Moreno, 1996). It has an ability to tie data and physical principles into comprehensive and effective representations of the study area. The calculation will be ended as soon as the highest difference in heads from two iteration steps falls below the error tolerance.

\section{Methodology}

There are actually three main sections in order to achieve the objectives of this research; (1) understanding the natural system, (2) developing the hydrogeological model (conceptual model), and (3) applying the numerical groundwater flow model. Figure 3 shows the methodological step of this research.

The study background about hydrogeology and numerical models in this research was firstly developed by understanding the natural system which contained many different tasks. Literature reviews were undertaken by compiling published hydrogeological and numerical modelling guidelines and analyzing the previous reports about geology, hydrogeology, hydrology of Yogyakarta and numerical models which were already created in the past. The outcomes of the literature reviews led to the preliminary understanding of the natural system and enable us to define the step of data acquisition for the site investigation. Then, the principal task on data acquisition was combining different data sources to obtain homogenous data set from several sources.

Developing the hydrogeological model conducted by combining results of literature study and the field investigation. Defining the boundary conditions of the study area was the main focus of hydrogeological condeptual model. Well distribution, borehole logs, piezometric head measurements from observation wells, groundwater abstraction from production wells, pumping tests, aquifer parameters such as hydraulic conductivity, effective porosity, and storage compressibility, surface water packages (e.g. surface water level, river beds thickness, and its hydraulic conductivity), and climatology data (e.g. precipitation, humidity and temperature) were collected from secondary data. On this stage, calculation of groundwater recharge was conducted by ap- 
plying some existing hydrological equations, as explained below.

Regarding the climate condition, the average annual rainfall in Yogyakarta City is about 2450 $\mathrm{mm}$ /year, with the annual mean temperature in Yogyakarta City is about $27.3^{\circ} \mathrm{C}$ (Iqbal, 2013). The estimation of the groundwater recharge was conducted based on simple water balance equation:

$$
U=P-E t r-R o
$$

where:

$U$ Groundwater recharge (mm/year)

$P$ Annual Precipitation (mm/year)

ETr Evapotranspiration Real (mm/year)

Ro Surface Runoff (mm/year)

ETr was calculated by applying TURC (1954) Equation (Singh, 1989), as written below:

$$
E T r=\frac{P}{\sqrt{0.9+\frac{P^{2}}{\left(300+25 \cdot T_{m}+0.05 \cdot T_{m}^{3}\right)^{2}}}}
$$

where:

Ro Runoff (cm/a)

$P$ Rainfall (cm/a)

$T_{m}$ Annual mean temperature $\left({ }^{\circ} \mathrm{C}\right)$

$A$ Watershed $\left(\mathrm{km}^{2}\right)$

Surface runoff was calculated by applying empirical runoff equation from Department of Agriculture of India (1990) which is proven to be suitable for Java Island - Indonesia (Institut Teknologi Bandung, 2001). The run off estimation based on this method is written as the following below:

$$
R o=\frac{1.511 \times P^{1.44}}{T_{m}^{1.34} \times A^{0.0613}}
$$

Applying the above equations, the groundwater recharge in the research area is found to be about $400 \mathrm{~mm} /$ year.
The numerical model is based on a program code which solves the groundwater equations. It has the general purpose to simulate a variety of specific hydrogeological model by varying input data. In this study, Visual Modflow software was used to solve the numerical problem. The program uses finite difference analysis to solve the groundwater flow equation in both saturated and unsaturated conditions. This study was focused on the simulation of groundwater flow model under saturated condition in both non time-dependent (steady state) models. Prediction of the optimum yield was conducted by comparing the effect of several groundwater abstraction values to the recent groundwater table condition.

Numerical models consist of governing equation, boundary conditions and initial conditions. Correct selection of the boundary conditions is a critical step in model design. In steady-state simulations, the boundaries largely determine the flow pattern. The model boundaries within the model domain selected for this model include few assumptions which are necessary to simplify the model numerically. Some assumptions have to be made for the model. The main assumptions are as follow: (1) the water table in the north and south boundaries is assume to be constant with time, (2) recharge rates used are assumed net long-term values, (3) the river stages are derived based on surface topography and field observations, (4) Hydraulic conductivities used are partly estimated and averaged over a large area based on pumping test well and field observations, (5) topographical information is sufficiently accurate, and (6) Interpolation and extrapolation of data is acceptable.

\section{Results}

The model domain selected measures about $90 \mathrm{~km}^{2}$ extending from $426500 \mathrm{mE}$ to $436500 \mathrm{mE}$ and $9133000 \mathrm{mN}$ to $9142000 \mathrm{mN}$ as shown in Figure 4. The hydrostratigraphic units whitin the model domain are discretized into 100 grid cell in the x-direction dan 90 grid cell in the $y$-direction. Each grid block consists of a homogeneous entity representing a sub-unit of 


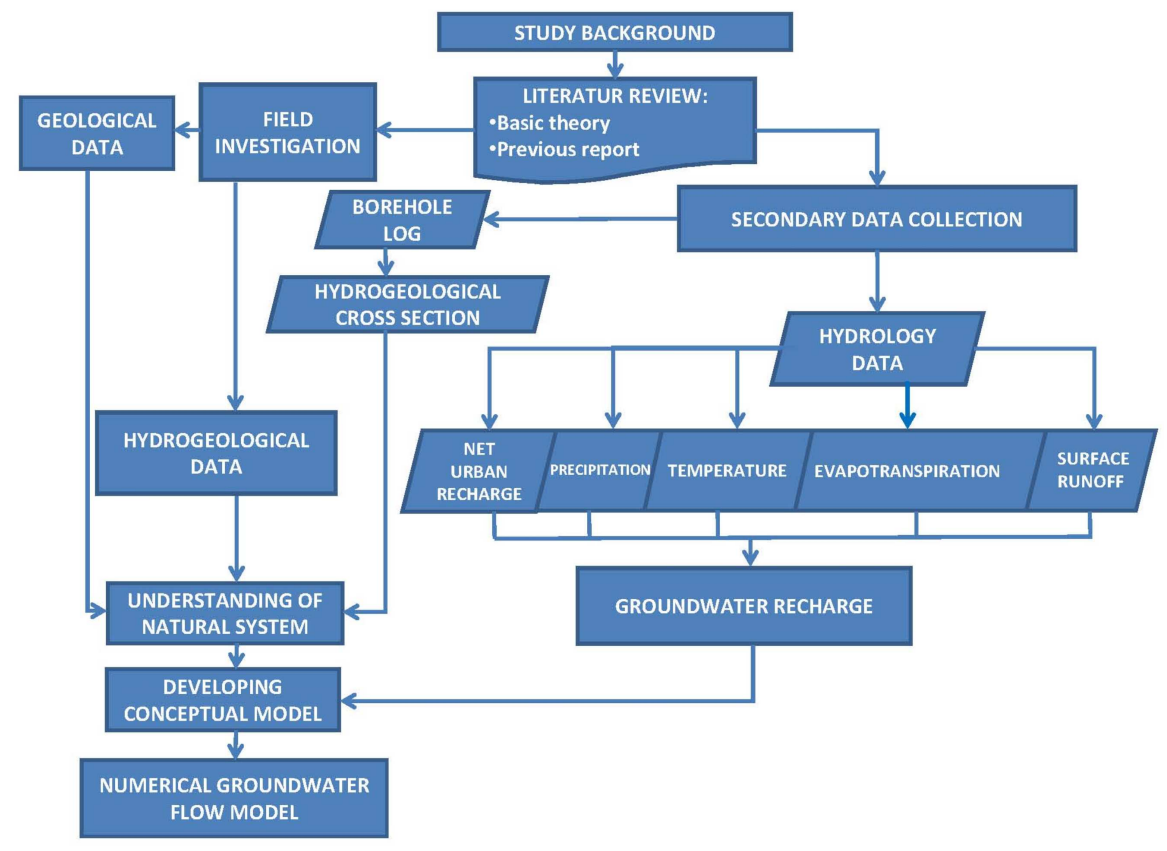

Figure 3: Flowchart of this research methodology.

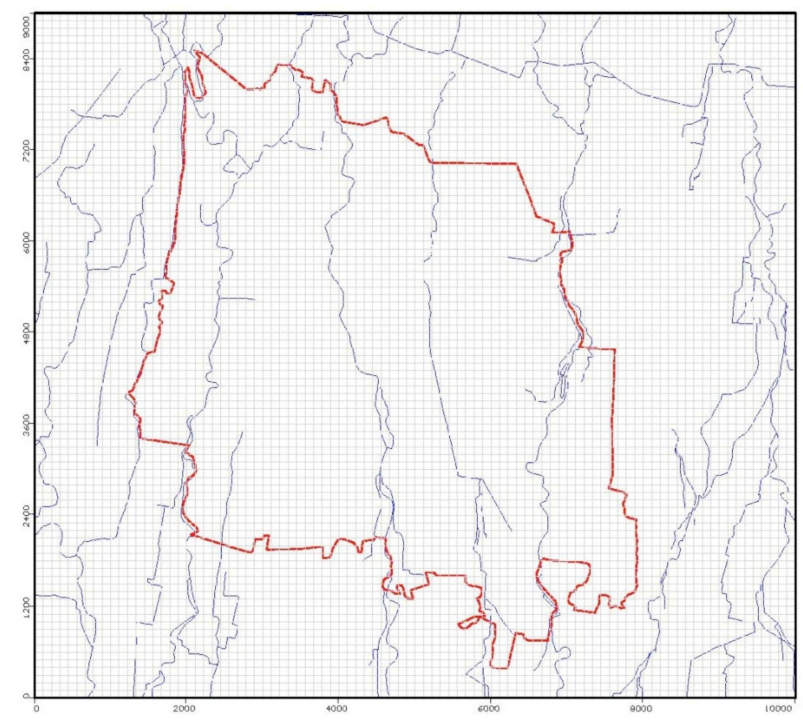

Figure 4: Discretization of the model area.

the hydrostratigraphic unit. Regular grid sizes are used in the model in order capture the full model domain and provde sufficient details and numerical stability in the areas of interest. Grid size measure $100 \mathrm{~m} \times 100 \mathrm{~m}$. The model consists of 7 layers which are bounded on top layer by topographical surface and on bottom layer by tertiary rocks (Sentolo Formation).

The hydrogeological boundaries in the cur- rent model are constant heads, recharge, and rivers boundaries as shown in Figure 5. The boundary of constant heads assigned to the northern and southern boundary of the model to represent constant water table boundaries. Recharge is assigned to be about $400 \mathrm{~mm}$ /year for whole area. Recharge to the model is essentially from rainfall infiltration; however in the model recharge to the aquifer system can also occur when the groundwater level is lower than the river stage. There are five river boundaries apply to the model; Bedog river, Winongo river, Code river, Gadjah Wong river and Tambak Bayan river. The surface water stages were measured in the upstream and downstream during dry and wet season of 2012 (Table 1).

In order to answer the objectives of the research, the influence of existing water well is considered in the model. Pumping test and field observation of existing wells indicated that drawdown caused by well is small due to the high permeability of the water bearing layers. Hydraulic conductivity of the aquifers in the model determines the ease with which groundwater moves within the aquifer systems. Based on the conceptual hydrogeological model, the hydraulic conductivity zones are identified and assigned to the model as shown in Figure6. The 
Table 1: Rivers condition in Yogyakarta city area.

\begin{tabular}{|l|c|c|c|c|c|c|c|c|c|c|}
\hline River & \multicolumn{2}{|c|}{ Bedog } & \multicolumn{2}{c|}{ Winongo } & \multicolumn{2}{c|}{ Code } & \multicolumn{2}{c|}{ Gajahwong } & \multicolumn{2}{c|}{ Tambak Bayan } \\
\hline & US & DS & US & DS & US & DS & US & DS & US & DS \\
\hline River stage (m) & 131 & 62 & 130 & 67 & 130 & 73 & 136 & 60 & 135 & 67 \\
\hline Riverbed bottom (m) & 130.2 & 61 & 126.5 & 66 & 127 & 71 & 134.5 & 58.7 & 133 & 66.1 \\
\hline
\end{tabular}

Note: US = upstream; DS = downstream

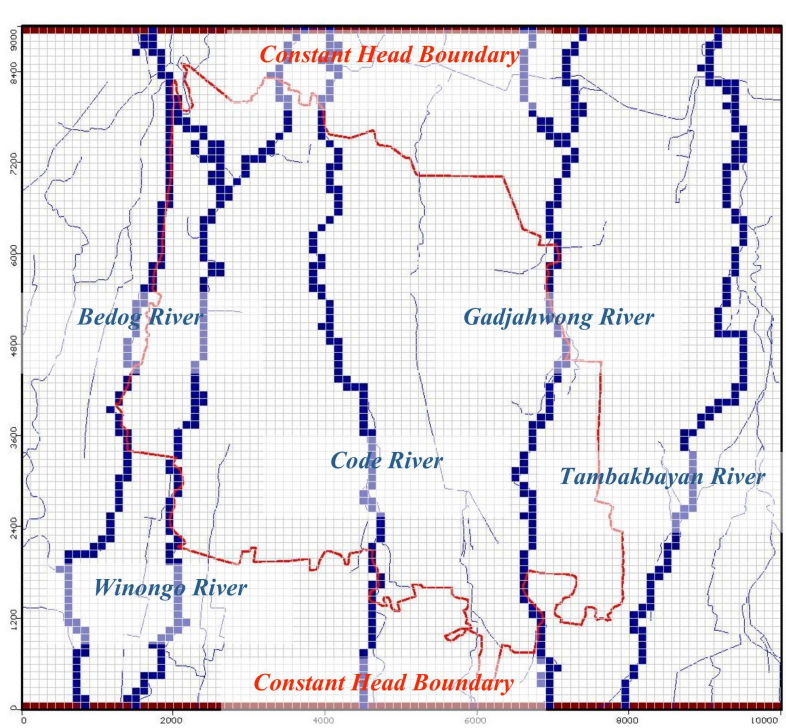

Figure 5: Boundaries assigned for the groundwater model.

vertical hydraulic parameters assigned same as the horizontal conductivity values. Aquifer storage parameters are not required in steadystate simulation. Result of the modeling is shown in Figure 7.

Due to understand the effect of groundwater withdrawals to the changes of water table in Yogyakarta city, a series of predictive sensitivity analysis are conducted in addition to the recent groundwater withdrawal scenario. The predictive sensitivity scenarios include:

Base case: groundwater withdrawals 43,472 $\mathrm{m}^{3} /$ day

Scenario 1: groundwater withdrawals 125,712 $\mathrm{m}^{3} /$ day

Scenario 2: groundwater withdrawals 377,136 $\mathrm{m}^{3} /$ day

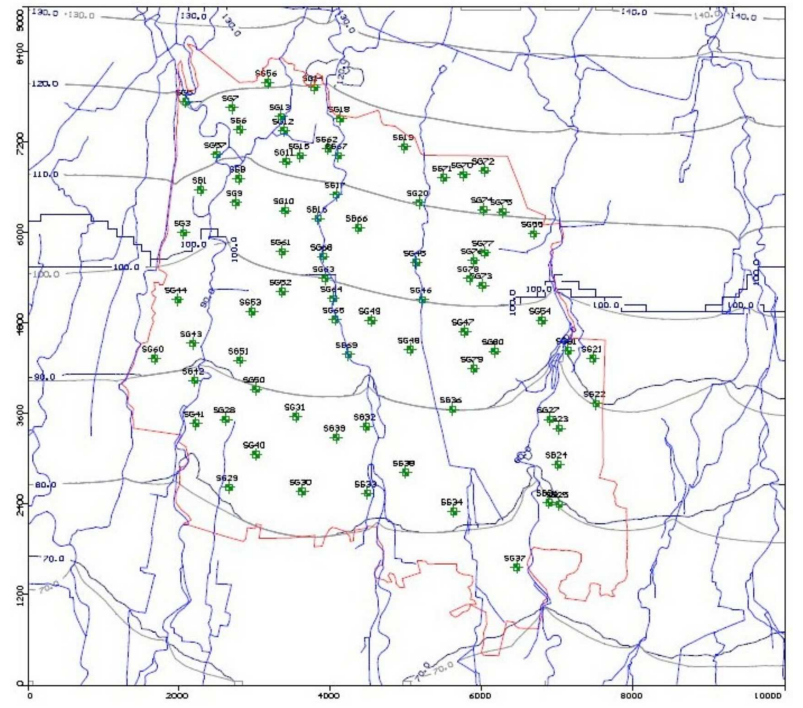

Figure 7: Simulated water table of Yogyakarta city.

Scenario 3: groundwater withdrawals 628,560 $\mathrm{m}^{3} /$ day

Scenario 4: groundwater withdrawals 758,592 $\mathrm{m}^{3} /$ day

Scenario 5: groundwater

withdrawals $1,137,888 \mathrm{~m}^{3} /$ day

Figure 8 shows the average of water table decrease in Yogyakarta city due to those several scenarios. The models show that the average decreases to $3 \mathrm{~m}$ of water table occur for basecase to scenario 3 compare to the water table in year 1984. However, if the existing groundwater withdrawals result only $8 \mathrm{~m}$ maximum decrease of water table, all the groundwater withdrawals of scenario 1 to 3 reveal maximum decrease of water table up to $11 \mathrm{~m}$. Scenario 4 and 5 shows merely worst effect to the decrease of water table than the other scenarios. 


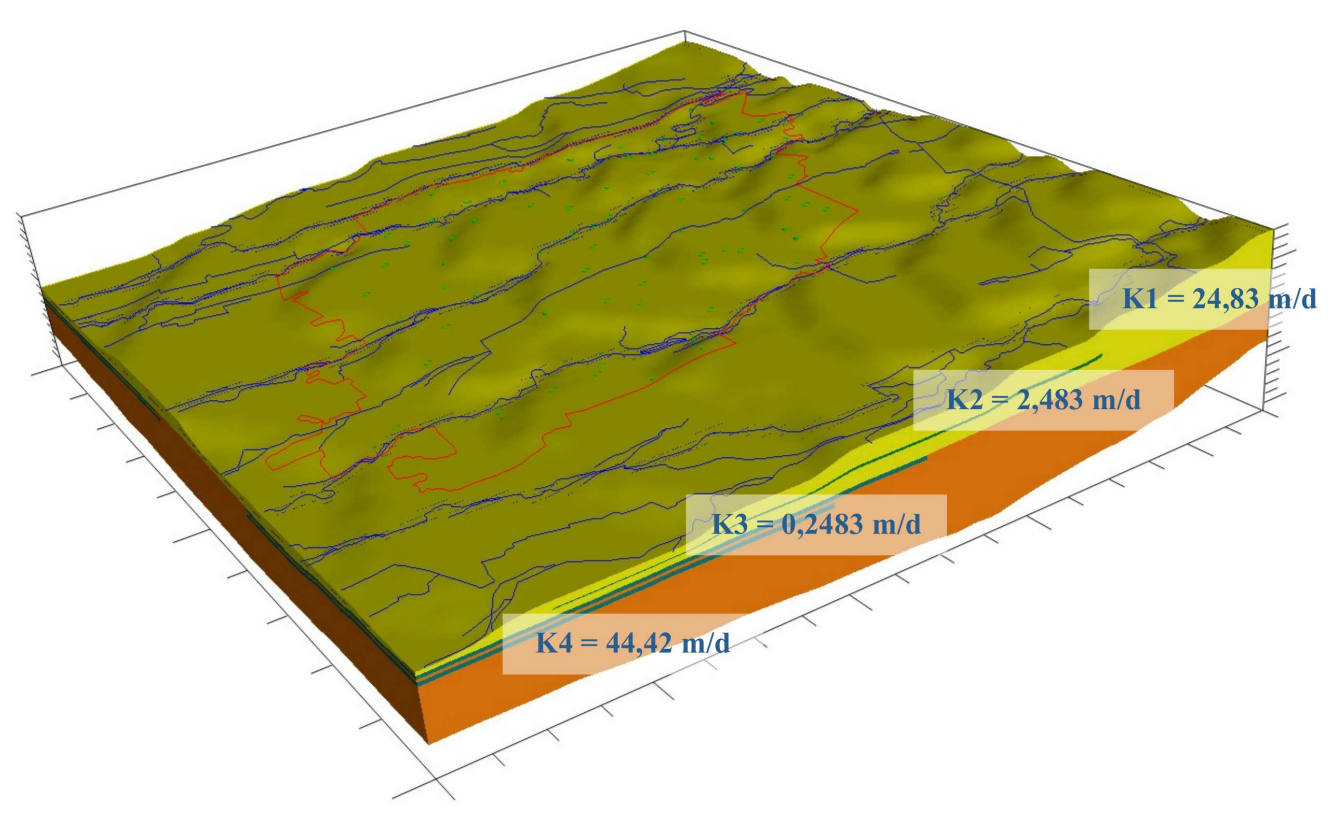

Figure 6: Hydraulic conductivity zones applied in the model.

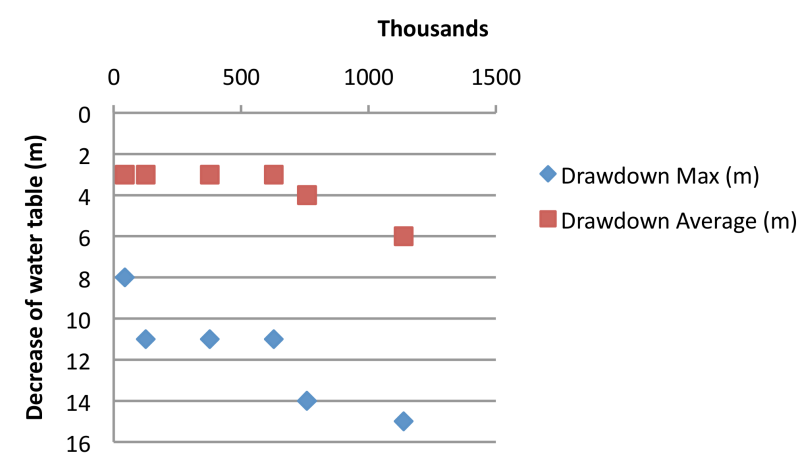

Figure 8: Total groundwater withdrawals versus decrease of water table.

\section{Discussion and conclusion}

Commonly, the optimum yield is calculated based on their effect to the drawdown of water table. The allowable drawdown of water table is up to $60 \%$ from the total thickness of aquifer. Considering that most of the people in the Yogyakarta City are still depends their water supply from shallow dug wells, it is wise if the optimum yield is calculated based on the common deep of dug wells (less than $12 \mathrm{~m}$ or about 25$30 \%$ from the total thickness of upper aquifer).

Based on the results of modelling, groundwater withdrawals of about $125,712 \mathrm{~m}^{3} /$ day from the aquifer of Yogyakarta City is already cause the decrease of water table to $3 \mathrm{~m}$ deeper than the recent condition (maximum drawdown). Therefore, for the case of Yogyakarta City, it can be concluded that the optimum yield of aquifer beneath this city should be about $125,000 \mathrm{~m}^{3} /$ day. This conclusion can be argued as the similar maximum drawdown are also occur for groundwater withdrawals up to 628,250 $\mathrm{m}^{3} /$ day, however it should be bear on mind that there are some limitations to the model, such as a constant head in the north and south boundaries which in the future may be change due to the expansion of city and human activities.

\section{References}

Freeze, R.A., and Cherry J.A. (1979) Groundwater, 604 p, Prentice-Hall, Inc., Englewood Cliffs, NJ.

Hendrayana, H. (1993) Hydrogeologie und Groundwassergewinnung Im Yogyakarta Becken, Indonesien, Dissertation, RWTH-Aachen.

Institut Teknologi Bandung (2001) Penelitian Cekungan Air Bawah Tanah Mojokerto, Jawa Timur, Dinas Pertambangan dan Energi Propinsi Jawa Timur.

Iqbal, M. (2013) Pemodelan Aliran Airtanah di Wilayah Kota Yogyakarta, Skripsi, Jurusan Teknik Geologi, Fakultas Teknik, Universitas Gadjah Mada.

MacDonald and Partners (1971) Kali Progo Basin Study - Part B: Groundwater, 95 p, Directorate 
General of Water Resources Development Project, Government of The Republic of Indonesia.

MacDonald and Partners (1984) Greater Yogyakarta Groundwater Resources Study Volume 3: Groundwater, 116 p, Directorate General of Water Resources Development Project (P2AT), Ministry of Public Works, Government of The Republic of Indonesia.

Putra, D.P.E (2007) The Impact of Urbanization on Groundwater Quality, A Case Study in Yogyakarta City - Indonesia, Mitteilungen zur Ingenieurgeologie und Hydrogeologie, Heft 96, 148 S, Okt 2007, Herausgegeben vom Lehrstuhl fuer In- genieurgeologie und Hydrogeologie, Univ.-Prof. Dr. R. Azzam, RWTH Aachen, Germany

Rahardjo, W., Sukandarrumidi and Rosidi, H.M.D. (1977) Geological map of Yogyakarta Quadrangle, Geological Survey of Indonesia, Bandung.

Singh, V.P. (1989) Hydrologic Systems Volume 2: Watershed Modeling, 320 p, Prentice-Hall Inc, New Jersey.

Spitz, K. and Moreno, J. (1996) A Practical Guide to Groundwater and Solute Transport Modeling, 461 p, John Wiley, New York. 